\title{
Coal Enrichment Methods by Using Microorganisms and Their Metabolites
}

\author{
Małgorzata Deska', Marcin Głodniok1*, Krzysztof Ulfig ${ }^{2}$ \\ 1 Central Mining Institute, Department of Water Protection, Plac Gwarków 1, 40-166 Katowice, Poland \\ 2 Medical University of Silesia in Katowice, Department of Public Health, Piekarska 18 St., 41-900 Bytom, Poland \\ * Corresponding author's e-mail: mglodniok@gig.eu
}

\begin{abstract}
The aim of this study is to review the literature on the methods of low-rank coal enrichment by using microorganisms and their metabolites. Effective bio-beneficiation technologies for low-rank coals in the future are also suggested throughout this paper. An extensive literature review highlights recent advances in bio-beneficiation technologies for low rank coals. This paper presents the state of the art in the field of the bio-beneficiation technology - carbon leaching with the aid of microorganisms, especially fungi. The knowledge of the low-rank coals leaching is an important step to meet the carbon eco-requirements and improve the economics of mining companies. There are several reasons to investigate microbial activities towards coal. This paper presents the current state of knowledge concerning bioleaching of coal. Thus, in view of the increasing importance of hard coal as a raw material and energy source, it seems hopeful to study the potential of microorganisms to modify the low-rank coal structure.
\end{abstract}

Keywords: low-rank coal, bioleaching, biodesulphurization, microorganisms

\section{INTRODUCTION}

The result of continuously increasing demand for energy is the depletion of fossil fuels. However, in most cases the quality of raw coals does not qualify them for further use and the coals must be adapted to the needs of users. About $50 \%$ of the world's total coal deposits are low rank coals. Adaptation of coal quality parameters to the requirements and needs of specific customers involves removing useless ingredients, e.g., stone, sand, pyritic sulphur, metals, etc. The processes of coal quality improvement are defined as the enrichment/beneficiation of coals. These processes are also an important step to meet the carbon eco-requirements and improve the economics of mining companies. Coal enrichment methods can be divided into physical (gravity and magnetic separation), chemical (leaching), physico-chemical (flotation and oil agglomeration) and biobeneficiation technologies using microorganisms (bioleaching). Physical and chemical methods, however, display a negative impact on the environment. Therefore, the need to develop environmentally friendly methods is still important [Xie and Peng 2015]. The idea that microorganisms (especially bacteria) might be able to modify the physico-chemical structure of coal is not new, but due to the heterogeneous structure of coal it has its own challenges. The microbial conversion of coal has attracted much attention through the past decades. While this technology has great potential, there is a number of involved problems to be solved. Such methods are known as bioleaching, bio-demineralization, and biodesulphurization. The removal of mineral matter from coal has been practiced since long time and it has been known that fungi and bacteria can conduct conversion of coals [Sand et al. 1992, Blazquez et al. 1993, Aller et al. 2001, Cardona and Marquez 2009, Kisielowska et al. 2010, Hong et al. 2013, Kim et al. 2013, Rossi 2014, Elcey and Manoj 2014]. Many of these processes have not reached widespread commercialization, due to the cost 
involved. So new eco-friendly and economically justified bioconversion technologies of coal are essentially needed to reduce environmental degeneration by this source of energy.

\section{LOW RANK COALS ENRICHMENT}

Coal is the complex of organic and inorganic compounds and water. Organic compounds are composed of carbon, oxygen, nitrogen, sulphur and many trace elements. From the geological point of view coal is a fossil solid fuel of dead-plant-remain origin. Coal inorganic compounds derive from the mire from water-borne or wind-borne sediments, muds, sand, mire water, dust, ash or elements in the original vegetation. The coal quality as fuel is determined by many factors, i.e., 1) percentage of fixed carbon; 2) moisture (inherent water); 3) volatile matter; 4) calorific value; and 5) content of mineral matter and sulphur. Coal rank can be classified as follows (from lowest to highest): lignite (called brown „,coal”), subbituminous coal, bituminous coal, and anthracite. Each group can be further classified with more details [Krasiński and Piwocki 2002, Schweinfurth 2009]. Leading countries in the mining of brown coal are: Germany, USA, Australia, Turkey, Russian Federation, countries of former Yugoslavia and Poland. In Poland the lignite has been exploited from more than 200 years. Currently, the lignite is being exploited in central (Bełchatów, Konin, Adamów) and south-eastern Poland (Turów) [Krasiński and Piwocki 2002, Bielowicz 2010]. Due to the fact that the lignite is a type of the coal geologically younger compared to the others, this fuel has been considered to be the most suitable for desulphurization by microorganisms. Moreover, sulphide as pyrite is poorly attached to this coal that makes sulphur easier to remove from the fuel [Aytar et al. 2008].

The capability of microorganisms to act on the fossil fuels have a great impact on the all mining industry. There are many different microorganisms involved in the elution (extraction) of various elements from coal, mainly throughout the formation of organic/inorganic acids. These microbial activities are promising to be efficiently applied in the mining industry for bio-beneficiation of low rank coals in the future [Rawling and Silver 1995].

\section{MECHANISMS OF BIOLEACHING}

Both fungi and bacteria may affect the coal by mobilizing metals using three mechanisms: (1) the production of organic/inorganic acids; (2) redox reactions; and (3) the excretion of complexing agents [Krebs et al. 1997). The main inorganic acid that is found in bioleaching environments is sulfuric acid and it is created by sulphur-oxidizing microorganisms, mainly bacteria from the genus Acidithiobacillus (previously known as Thiobacillus). A series of organic acids are produced by bacterial and fungal metabolism subsequent in organic acidolysis, complex and chelate formation [Brandl 2001].

The effectiveness of bioleaching depends on many factors, both on the microorganisms involved and on the structure and composition of substrate to be leached, and also on physicochemical parameters of the material under bioleaching. The microbiological factors affecting bioleaching are as follows: microbial diversity, population density, microbial activities, metal resistance, spatial distribution, and adaptation abilities. In turn, the physicochemical factors include $\mathrm{pH}$, temperature, redox potential, water potential, oxygen content and availability, carbon dioxide content, mass transfer, nutrient availability, iron (III) concentration, light, pressure, surface tension, and the presence of process inhibitors. Finally, properties of the solids are also important in the bioleaching process. These properties are the following: mineral composition, grain size, surface area, porosity, hydrophobicity, galvanic interactions, and the formation of secondary minerals. Bioleaching techniques have several advantages in comparison to chemical leaching [Krebs et al. 1997, Brandl 2001].

The metals can be removed from sulphide minerals by direct and indirect mechanisms of bacterial leaching [Bosecker 1997].

\section{BACTERIAL BIOLEACHING OF COAL}

Singh, Singh, Kumar and Singh (2012) used mixed bacterial consortium as an effective tool for removing toxic trace metals in sub-bituminous coal from Tarakan basin of Kalimantan (Indonesia). The data obtained showed that more than $80 \%$ of metals like $\mathrm{Ni}, \mathrm{Zn}, \mathrm{Cd}, \mathrm{Cu}$ and $\mathrm{Cr}$ was removed, while $\mathrm{Pb}$ was removed only by $45 \%$. 
Desulfurization by microbiological methods involves the removal of sulphur compounds from coal using different microorganisms. The sulphur content most often varies between $0.05-7 \%$. It may occur both in nonorganic compounds (sulphides, sulphates (IV, VI)) and organic compounds (alkyl, aryl derivatives of hydrogen sulphide). During combustion of coal the sulphur dioxide is emitted to air, where it can react with water and oxygen, leading to the formation of sulphuric acid (IV), (VI). It is widely accepted that high concentrations of sulphur in coal has a negative influence on its utilization. It has a negative impact on the environment due to the formation of acid rains. High costs of flue gas desulphurization prompted to look for other methods of coal desulfurization, including biological methods using microorganisms as key agents [Fecko et al. 2002, Fecko et al. 2006, Aytar et al. 2008].

Mining environments seem to be relatively poor in the diversity of their microflora. Nevertheless, the microorganisms of these environments represent unique qualitative and quantitative compositions. There has been a significant increase in our knowledge and understanding of both the microbial biodiversity of mining waters and interactions between microorganisms inhabiting them [Johnson 1998, Hallberg and Johnson 2001, Johnson 2008].

Bioleaching of coal is effected by bacteria such as Acidithiobacillus ferrooxidans, Acidithiobacillus thiooxidans, Mycobacterium phlei, Rhodococcus rhodochrous, Leptospirillum ferrooxidans, Sulfolobus solfataricus, and Acidianus brierleyi. Also the fungi are involved in the coal leaching process. These include: Aspergillus sp., Penicillium sp., Rhizopus sp., Mucor sp., Cladosporium sp. Pleurotus sajor-caju, Trametes versicolor, Phanerochaete chrysosporium, Alternaria sp. and others [Acharya et al. 2001, Aller et al. 2001, Cardona and Marquez 2009, Kisielowska et al. 2010, Gonsalvesh et al. 2012, Kim et al. 2013, Manoj 2013, Rossi 2014, Elcey and Manoj 2014, Aytar et al. 2014].

The mesophilic bacterium Acidithiobacillus ferrooxidans is most often applied in coal biodesulfurization, including pyrite sulphur bioleaching [Aller et al. 2001; Cardona and Marquez 2009, Kim et al. 2013, Rossi, 2014]. The results showed that these bacteria significantly promoted the biodesulfurization of coal [Hong et al., 2013]. Abdel-Khalek and El-Midany [2013] demonstrated that Mycobacterium phlei increased the coal separation selectivity from its associated impurities and reduced the total sulphur and ash $0.9 \%$ and $2.1 \%$, respectively.

Biological sulphur removing from coal requires usually simple, but on occasions extensive installations. In both cases the energy consumption is considered to be low. Sulphur occurs in coal in two forms: organic and inorganic. Removal of the inorganic sulphur (80-90\%) is relatively easy by using microbial cultures. Acharya et al. [2001] used three different types of coal for microbial desulfurization by $A$. ferrooxidans. The data showed that the maximum removal of sulphur were $91.81 \mathrm{wt} \%$ for Rajasthan lignite, $63.17 \mathrm{wt} \%$ for Polish bituminous coal and merely $9.41 \mathrm{wt} \%$ for Assam coal. Sulfolobus solfataricus (ATCC 35091) were tested as the microorganism active in the coal biodesulphurization process by Gonsalvesh et al. (2012). Maximum effect of biodesulphurization due to further total sulphur decrease $\left(\Delta \mathrm{S}_{\mathrm{t}}\right) 16.9 \%$ and organic sulphur decrease $\left(\Delta \mathrm{S}_{\mathrm{o}}\right) \quad 18.3 \%$ were recorded for $S$. solfataricus [Gonsalvesh et al., 2012]. Biodesulphurization of Turkish lignite using Rhodococcus rhodochrous was conducted by Bozdemir, Durusoy, Erincin and Yurum [1996]. At $75 \mathrm{~h}$ of biodesulfurization with Mengen lignite they obtained decreases in the total sulphur by $30.2 \%$ and organic sulphur by $27.1 \%$ [Bozdemir et al., 1996]. While sodium acetate was used as substrate the highest removal rates of organic sulphur (27.1\%) was obtained by Durusoy, Bozdemir, Erincin and Yürüm [1997]. Moreover, it was demonstrated that the biodesulphurization rate decreased with increasing particle size in a hyperbolic mode [Erincin et al. 1998]. The desulphurization of coal from Mae Moh lignite mine (Thailand) by Acidithiobacillus ferrooxidans (ATCC19859) was conducted by Ruamsap and Akaracharanya [2002]. In this study $A$. ferrooxidans was able to remove $11.52 \%$ of the total pyritic sulphur from lignite under the optimal conditions. However, Polish researchers [Machnikowska, et al. 2002] tested the strain of Pseudomonas putida (obtained from the collection of the Institute of Immunology, Polish Academy of Sciences, Wrocław) for degradation of organic matter in lignites and subbituminous coals from Polish mines. The limited ability of this strain for coal organic matter degradation was demonstrated. Kisielowska, Hołda and Młynarczykowska [2014] presented the results of coal biodesulphurization in the Halemba mine (Poland) with the use of indigenous Acidithioba- 
cillus thioparus bacteria and taking into account the grain-size distribution and the amount of biomass. In this study $A$. thioparus was able to remove $30 \%$ of the total sulphur from coal.

\section{DIRECT BACTERIAL LEACHING}

The mechanism of the direct leaching relies on the oxidation process, in which electrons are obtained directly from reduced minerals. In this model, there is a physical, close contact between the bacterial cell and the surface of the mineral. Bacterial cells attach to the specific sites on the mineral surface. These reactions consist mainly of pyrite oxidation. Therefore pyritic iron (II) is oxidized to iron (III) sulphate according to the following reactions (Bosecker, 1997; Brandl, 2001):

$$
\begin{aligned}
& 4 \mathrm{FeS}_{2}+14 \mathrm{O}_{2}+4 \mathrm{H}_{2} \mathrm{O} \rightarrow 4 \mathrm{FeSO}_{4}+4 \mathrm{H}_{2} \mathrm{SO}_{4} \\
& 4 \mathrm{FeSO}_{4}+\mathrm{O}_{2}+2 \mathrm{H}_{2} \mathrm{SO}_{4} \rightarrow 2 \mathrm{Fe}_{2}\left(\mathrm{SO}_{4}\right)_{3}+2 \mathrm{H}_{2} \mathrm{O}
\end{aligned}
$$

It can be summarized by the reaction:

$4 \mathrm{FeS}_{2}+15 \mathrm{O}_{2}+2 \mathrm{H}_{2} \mathrm{O} \rightarrow 2 \mathrm{Fe}_{2}\left(\mathrm{SO}_{4}\right)_{3}+2 \mathrm{H}_{2} \mathrm{SO}_{4}$

\section{INDIRECT BACTERIAL LEACHING}

The indirect mechanism (non-contact leaching mechanism) generally consists of the oxidizing action of iron (III) ions that dissolve a metal sulphide. During this process, iron (II) ions and elemental sulphur (S) are generated. The adhesion of cells to the sulphide mineral is not required in this mechanism. Both the direct and indirect mechanisms may undergo simultaneously together with other physico-chemical reactions in all bioleaching systems. [Brandl 2001, Sand et al. 2001, Vera et al. 2013].

Nevertheless, the model of „direct” and ,indirect" bioleaching still remains to be studied and discussed. Recently, this model has been revised and replaced by another one, which is not dependent on the differentiation between "direct" and ,indirect" leaching mechanisms. The newly developed integral bioleaching model was described and discussed by many authors [Sand et al. 1995, Sand et al. 1999; Sand et al. 2001, Tributsch 2001]. The model includes combined „direct" and ,indirect" bioleaching and can be characterized in the following way: at first, physical contact of bacterial cells with surface of min- erals are needed, then the cells produce and secrete exopolymers (extracellular polymeric substances EPS). These exopolymeric cell envelopes contain ferric iron compounds which are complexed to glucuronic acid residues. This is part of the primary attack mechanism. During the sulphur compounds oxidation thiosulfate is formed as intermediate. Sulphur or polythionate granules are produced in the periplasmatic space or in the cell envelope [Brandl, 2001].

There is some evidence of a beneficial effect of extracellular polymeric substances (EPS) on bioleaching process [Pogliani and Donati 1999, Sand et al. 2001, Kinzlera et al. 2003].

\section{FUNGI BIOLEACHING OF COAL}

Although much of the work on coal bioleaching has been attempted with various bacteria, relatively little data are available on coal bioleaching with fungi. Fungi are able to metabolize a wide range of anthropogenic chemicals and hydrocarbons via the action of cytochrome p-450 and extracellular enzymes [Van Hamme et al. 2003; Aytar et al., 2008, Adegunlola et al. 2012]. The lignin polymer bears a strong structural similarity to lignite, so, it seems possible that whiterot fungi may use their lignolytic systems in the biodesulphurization of coal and/or petroleum. The lignolytic enzyme system consists mainly of peroxidases (manganese peroxidase (MnP, EC 1.11.1.13), lignin peroxidase (Lip; EC 1.11.1.14), and other peroxidases), phenol oxidase (laccase, EC 1.10.3.2), supporting enzymes (e.g., $\mathrm{H}_{2} \mathrm{O}_{2}$ generating oxidases) and the production of lowmolecular-weight organic acids such as oxalate, malate, malonate (Fakoussa and Hofrichter, 1999). During the oxidative desulphurisation of Turkish lignites with crude laccase produced by Trametes versicolor ATCC 200801, 35\%, 13\%, and $25 \%$ reductions were obtained for pyritic sulphur, sulphate and organic sulphur, respectively, in a period of $30 \mathrm{~min}$. It is noteworthy that no change in coal calorific values was recorded [Aytar et al. 2011].

As mention above, the coal biosolubilisation by fungi is associated with the production of organic acids such as gluconic acid, oxalic acid and citric acid. Oxalates are responsible for the demineralization of coal by the formation of mineral salts. The HPLC profile revealed the presence of organic acids such as citric acid, oxalic 
acid and gluconic acid along with acetyl-CoA and oxaloacetate (Tab. 1) [Ramachandran et al. 2006, Kisielowska et al. 2010, Manoj 2013, Elcey and Manoj, 2014].

The effect of the demineralization of Indian bituminous coal by the filamentous fungus, $A s$ pergillus niger, was studied by Elcey and Manoj [2014]. The ash content in the coal significantly decreased (from $10.23 \mathrm{wt} \%$ to $5.21 \mathrm{wt} \%$ ) during bioleaching by the above-mentioned fungus (Tab. 2). The changes in surface morphology, functional groups and structure were also studied [Manoj 2013, Elcey and Manoj 2014].

Elcey and Manoj [2013] also demonstrated that filamentous fungi, A. niger, A. flavus and Penicillium spp. were able to demineralize the low rank coals from India. Acharya, Sukla and Misra [2005] studied the degree of sulphur elimination from high sulphur Assam coal by the native fungal strain, Aspergillus sp. The strain eliminated $78 \%$ of the total sulphur content with coal grain size of $0.074 \mathrm{~mm}$ in 10 days of extraction time with $2 \%(\mathrm{w} / \mathrm{v})$ pulp density.

In another study, the desulphurization by $\mathrm{Al}$ ternaria sp. was effective on the lignite sample with the size of $0.106+0.038 \mathrm{~mm}$ [Aytar et al., 2014]. Phanerochaete chrysosporium (ME446) was tested for coal biodesulphurization by Gon-

Table 1. Organic material secreted during the bioleaching [Manoj 2013]

\begin{tabular}{|c|l|}
\hline Retention time & \multicolumn{1}{|c|}{ Organic material } \\
\hline 2.767 & Acetyl-CoA \\
\hline 4.601 & Iso-citric acid \\
\hline 4.791 & Glucose/Galactose \\
\hline 5.344 & Fructose \\
\hline 5.608 & Acetic acid \\
\hline 6.397 & Riboflavin \\
\hline 6.838 & Oxalic acid/Oxalate \\
\hline 7.775 & Citric acid \\
\hline 8.688 & Pyruvate Carboxylase \\
\hline 9.503 & Pyruvate Carboxylase \\
\hline 10.768 & a-ketoglutaric acid \\
\hline 14.151 & Gluconic acid \\
\hline 36.686 & 3-hydroxybenzoic acid \\
\hline
\end{tabular}

salvesh et al. [2012]. Maximum effect of biodesulfurization due to further total sulphur decrease $\left(\Delta \mathrm{S}_{\mathrm{t}}\right)$ of $24.2 \%$ and further organic sulphur decrease $\left(\Delta \mathrm{S}_{\mathrm{o}}\right)$ of $23.8 \%$ was recorded for Phanerochaete chrysosporium. The Penicillium citrinum strain was examined for coal degradation capabilities by Polman, Stoner and Delezene-Briggs [1994]. The results suggested a potential usefulness of this strain for coal bioprocessing. Gonsalvesh et al. [2012] used different types of microorganisms, i.e., Trametes versicolor (ATCC No. 200801), Phanerochaete chrysosporium - ME446, Pleurotus sajor-caju and one mixed bacterial culture for biodesulfurization of coal from „Pirin” basin (Bulgaria). A high degree of inorganic sulphur elimination was obtained with mixed bacterial culture (79\%) followed by $13 \%$ for organic sulphur $\left(\mathrm{S}_{\mathrm{o}}\right)$ with Phanerochaete chrysosporium and Trametes versicolor [Gonsalvesh et al. 2008]. The biodesulphurization process was conducted by microorganisms that were isolated from Mihaliccik region (Eskisehir, Turkey) lignites. The lignites were characterized by high ash and sulphur content. The results demonstrated that the treatment of the lignites with the lignite-derived Alternaria sp. (endophytic fungus) removed $52 \%$ of the total sulphur content. After fungal desulphurization, organic sulphur and sulphate removals were $38 \%$ and $51 \%$, respectively [Aytar et al. 2014].

The bioleaching experiments were also carried out on Tuncbilek lignite, characterized by a high total sulphur content $(2.59 \%)$. The lignite was treated with white-rot fungi, i.e., Trametes versicolor ATCC 200801 and Phanerochaete chrysosporium ME 446. The effects of different operating parameters such as $\mathrm{pH}$, temperature, pulp density, incubation time, particle size on this process were evaluated. It was concluded that these fungi have good potential for application in the coal bio-desulfurization technology [Aytar et al. 2008].

Holker, Fakoussa and Hofer [1995] showed that the filamentous fungus, Fusarium oxysporum, was able to solubilize low-rank coal in the absence of glutamate or gluconate as carbon

Table 2. C,H,N,S and O content of KX coal before and after biosolubilisation by A. niger [Manoj 2013].

\begin{tabular}{|l|c|c|c|c|c|c|}
\hline \multirow{2}{*}{ Sample of coal } & \multicolumn{5}{|c|}{ Elemental analysis, wt\% (daf) } & \multicolumn{2}{c|}{ Ash \% } \\
\cline { 2 - 7 } & $\mathrm{C}$ & $\mathrm{H}$ & $\mathrm{N}$ & 0.33 & 22.6 & 10.23 \\
\hline KX (raw) & 69.9 & 5.68 & 1.50 & 2.01 & 0.33 & 10.76 \\
\hline KA (biosolubilized by A. niger) & 83.14 & 3.70 & 5.21 \\
\hline
\end{tabular}


sources. Igbinigie et al. [2008] isolated the ascomycete, Neosartorya fisheri, from the root zone of the grass, Cynodon dactylon, growing on coal dumps. The fungus was actively involved in the transformation of coal [Igbinigie et al. 2008, Mukasa-Mugerwa et al. 2011].

\section{CONCLUSIONS}

Among the natural resources, coal is the most important non-renewable energy source of fossil origin. Nevertheless, mineral matter and sulphur in coal place enormous limitations on its use. Conventional methods, to remove the mineral matters such as precipitation, filtration, ion exchange, adsorption, electrochemical treatment, etc., are unproductive when the additive concentration is very low in nature and the byproducts of any of these processes lead to another set of environmental pollutants.

Bioleaching application for coal enrichment by fungi, acidophilic autotrophs and heterotrophs is a valuable process to remove mineral content. Currently, most of the abandoned postindustrial and mine sites are recognized by the presence of microorganisms which can be isolated and screened in bioleaching of coal mineral pollutants. These abandoned sites contain the microbes those can tolerate very high concentration of different pollutants. These cells can be considered as suitable catalyst for industrial application of bioleaching. Such application can reduce the residence time and simultaneously enhance the economy of the process. In most of the bioleaching of industrial solid waste, the detail bacterial physiological role has not been established yet. Industrial waste containing different elements and how bacteria interact with individual elements need further research.

Therefore, looking for new, environmentally friendly methods of coal beneficiation is very important. Biologically based systems for the processing of coal continue to be a viable topic for scientific research and commercial development. Conducted analyses shown that use of fungi can reduce fly ash content up to $73 \%$ from initial value when treated with mixed culture of Aspergillus niger and Penicillium ssp. [Manoj 2010]. Such results causing significant reduction of ash concentration, improve value and quality of coals.

\section{REFERENCES}

1. Abdel-Khalek M.A., El-Midany A.A. 2013. Coal - Mycobacterium phlei interaction and its effect on coal cleaning. Tenside Surfactants Detergents, 50(6), 414-419.

2. Adegunlola G.A., Oloke J.K., Majolagbe O.N., Adebayo E.A. Adegunlola C.O., Adewoyin A.G., Adegunlola F.O. 2012. Microbial desulphurization of crude oil using Aspergillus flavus. European Journal of Experimental Biology, 2(2), 400-403.

3. Aller A., Martınez O., De Linaje J.A., Mendez R., Moran A. 2001. Biodesulphurization of coal by microorganisms isolated from the coal itself. Fuel processing technology, 69(1), 45-57.

4. Aytar P., Aksoy D.O., Toptas Y., Cabuk A., Koca S., Koca H. 2014. Isolation and characterization of native microorganism from Turkish lignite and usability at fungal desulphurization. Fuel, 116, 634641. doi:10.1016/j.fuel.2013.08.077

5. Aytar P., Gedikli S., Samb M., Ünal A., Cabuk A., Kolankaya N., Yurum A. 2011. Desulphurization of some low-rank Turkish lignites with crude laccase produced from Trametes versicolor ATCC 200801. Fuel Processing Technology, 92(1), 71-76.

6. Bielowicz, B. 2010. New technological classification of lignite as a basis for balanced energy management. Gospodarka Surowcami Mineralnymi, 26(2), 25-39.

7. Blazquez M. L., Ballester A., Gonzalez F., Mier J.L. 1993. Coal biodesulphurization: a review. Biorecovery, 2, 155-177.

8. Bosecker K. 1997. Bioleaching: metal solubilisation by microorganisms. FEMS Microbiology Reviews, 20(3-4), 591-604.

9. Bozdemir T.O., Durusoy T., Erincin E., Yurum Y. 1996. Biodesulfurization of Turkish lignites: 1. optimization of the growth parameters of Rhodococcus rhodochrous, a sulfur-removing bacterium. Fuel, 13(75), 1596-1600. doi:10.1016/0016-2361 (96)00118-4

10. Brandl H. 2001. Microbial Leaching of Metals, in Biotechnology Set, Second Edition (eds H.-J. Rehm, G. Reed), Wiley-VCH Verlag GmbH, Weinheim, Germany. doi: 10.1002/9783527620999. ch8k

11. Cardona I.C., Marquez M.A. 2009. Biodesulfurization of two Colombian coals with native microorganisms. Fuel Processing Technology, 90(9), 1099-1106. doi: 10.1016/j.fuproc.2009.04.022

12. Durusoy T., Bozdemir T.O., Erincin E., Yurum Y. 1997. Biodesulfurization of Turkish lignites: 2. Microbial desulfurization of Mengen lignite by the mesophilic microorganism Rhodococcus rhodochrous. Fuel, 76(4), 341-344. doi:10.1016/ S0016-2361(96)00237-2 
13. Elcey C.D., Manoj B. 2014. Investigation on biosolubilization of coal by Aspergillus Niger. Chemical Science Transactions, 3(3), 1200-1206. doi: $10.7598 /$ cst2014.824

14. Erincin E., Durusoy T., Bozdemir, T.O., Yurum, Y. 1998. Biodesulphurization of Turkish lignites. 3. The effect of lignite type and particle size on microbial desulfurization by Rhodococcus Rhodochrous. Fuel, 77(9-10), 1121-1124.

15. Fecko P., Ovcari P., Farkasova A. 2002. Bacterial desulphurisation of coal. Polish Geological Institute Special Papers, 7, 87-92.

16. Fecko P., Pectova I., Cablik V., Riedlova S., Ovcari P., Tora B. 2006. Bacterial desulphurization of coal. Górnictwo i Geoinżynieria, 30(3/1), 47-65.

17. Gonsalvesh L., Marinov S.P., Stefanova M., Carleer R., Yperman J. 2012. Organic sulphur alterations in biodesulphurized low rank coals. Fuel, 97, 489-503. doi:10.1016/j.fuel.2012.02.015

18. Gonsalvesh L., Marinov S.P., Stefanova M., Yurum Y., Dumanli A.G., Dinler-Doganay G., Kolankaya N., Sam M., Carleer R., Reggers G., Thijssen E., Yperman J. 2008. Biodesulphurized subbituminous coal by different fungi and bacteria studied by reductive pyrolysis. Part 1: Initial coal. Fuel, 87(12), 2533-2543. doi:10.1016/j.fuel.2008.01.030

19. Hallberg K.B., Johnson D.B. 2001. Biodiversity of acidophilic prokaryotes. Advances in Applied Microbiology, 49, 37-84.

20. Holker U., Fakoussa R.M., Hofer M. 1995. Growth substrates control the ability of Fusarium oxysporum to solubilize low-rank coal. Applied Microbiology and Biotechnology, 44(3-4), 351-355.

21. Hong F.-F., He H., Liu J.-Y., Tao X.-X., Zheng L., Zhao Y.-D. 2013. Comparison analysis of coal biodesulfurization and coal's pyrite bioleaching with Acidithiobacillus ferrooxidans. The Scientific World Journal, (1-9). doi:10.1155/2013/184964

22. Igbinigie E.E., Aktins S., Van Breugel Y., Van Dyke S., Davies-Coleman M.T., Rose P.D. 2008. Fungal biodegradation of hard coal by a newly reported isolate, Neosartorya fischeri. Biotechnology Journal, 3(11), 1407-16. doi: 10.1002/biot.200800227

23. Johnson D.B. 1998. Biodiversity and ecology of acidophilic microorganisms. FEMS Microbiology Ecology, 27(4), 307-317. doi:10.1016/ S0168-6496(98)00079-8

24. Kasiński J.R., Piwocki M. 2002. Low-rank coals in Poland: prospection - mining - progress. Polish Geological Institute Special Papers, 7, 17-30.

25. Kim D.J., Gahan C.S., Akilan C., Choi S.Y., Kim B. G. 2013. Microbial desulfurization of three different coals from Indonesia, China and Korea in varying growth medium. Korean Journal of Chemical Engineering, 30(3), 680-687.
26. Kinzler K., Gehrke T., Telegdi J., Sand, W. 2003. Bioleaching-a result of interfacial processes caused by extracellular polymeric substances (EPS). Hydrometallurgy, 71(1-2), 83-88.

27. Kisielowska E., Hołda A., Młynarczykowska A. 2014. Biodesulphurisation of coal with the use of Acidithiobacillus thioparus bacteria. Przegląd Górniczy, 70(5), 124-128.

28. Kisielowska E., Hołda A., Niedoba T. 2010. Removal of heavy metals from coal medium with application of biotechnological methods. Górnictwo i Geoinżynieria, 34(4/1), 93-104.

29. Krebs W., Brombacher C., Bosshard P.P., Bachofen R. Brandl, H. 1997. Microbial recovery of metals from solids. FEMS Microbiology Reviews, 20(34), 605-617.

30. Machnikowska H., Pawelec K., Podgórska A. 2002. Microbial degradation of low rank coals. Fuel Processing Technology, 77-78(20), 17-23.

31. Manoj B. 2013. Bio-demineralization of Indian bituminous coal by Aspergillus niger and characterization of the products. Research Journal of Biotechnology, 8(3), 49-54.

32. Manoj B., Elcey C.D. 2013. Demineralization of sub-bituminous coal by fungal leaching: a structural characterization by X-ray and FTIR analysis. Research Journal of Chemistry and Environment, 17(8), 11-15.

33. Mukasa-Mugerwa T.T., Dames J.F., Rose P.D. 2011. The role of a plant/fungal consortium in the degradation of bituminous hard coal. Biodegradation, 22(1), 129-41. doi: 10.1007/ s10532-010-9382-8

34. Pogliani C., Donati E. 1999. The role of exopolymers in the bioleaching of a non-ferrous metal sulphide. Journal of Industrial Microbiology \& Biotechnology, 22(2), 88-92.

35. Polman J.K., Stoner D.L., Delezene-Briggs K.M. 1994. Bioconversion of coal, lignin, and dimethoxybenzyl alcohol by Penicillium citrinum. Journal of Industrial Microbiology \& Biotechnology, 13(5), 292-299.

36. Ramachandran S., Fontanille P., Pandey A., Larroche C. 2006. Gluconic acid, properties, applications and microbial production. Food Technology and Biotechnology, 44 (2), 185-195.

37. Rawling D.E., Silver S. 1995. Mining with microbes. Nature Biotechnology, 13, 773-778. doi:10.1038/nbt0895-773

38. Rossi G. 2014. The microbial desulfurization of coal. Advances in Biochemical Engineering/Biotechnology, 142, 147-167. doi: 10.1007/10_2013_178

39. Ruamsap N., Akaracharanya A. 2002. Pyritic sulfur removal from lignite by Thiobacillus ferrooxidans: 
optimization of a bioleaching process. The Journal of Scientific Research, Chulalongkorn University, 27(2), 155-163.

40. Sand W., Gehrke T., Hallmann R., Schippers A. 1995. Sulfur chemistry, biofilm, and the (in)direct attack mechanism - a critical evaluation of bacterial leaching. Applied Microbiology and Biotechnology, 43(6), 961-966.

41. Sand W., Gehrke T., Jozsa P. -G., Schippers A. 2001. (Bio)chemistry of bacterial leaching direct vs. indirect bioleaching. Hydrometallurgy, 59(23), 159-175.

42. Sand W., Gehrke T., Jozsa P.-G., Schippers A. 1999. Direct versus indirect bioleaching. Process Metallurgy, 9(27-49). doi:10.1016/ S1572-4409(99)80004-2

43. Sand W., Rhode K., Sobotke B., Zenneck C. 1992. Evaluation of Leptospirillum ferrooxidans for leaching. Applied and Environmental Microbiology, 58(1), 85-92.
44. Schweinfurth S.P., 2009. An introduction to coal quality, [in:] Pierce B.S., Dennen K.O., eds., The National Coal Resource Assessment Overview: U.S. Geological Survey Professional Paper 1625F, Chapter C, 16 p.

45. Singh P.K., Singh A.L., Kumar A., Singh M.P. 2012. Mixed bacterial consortium as an emerging tool to remove hazardous trace metals from coal. Fuel, 102, 227-230. doi:10.1016/j.fuel.2012.06.039

46. Tributsch H. 2001, Direct versus indirect bioleaching. Hydrometallurgy, 59, 177-185. doi:10.1016/ S0304-386X(00)00181-X

47. Vera M., Schippers A., Sand W. 2013. Progress in bioleaching: fundamentals and mechanisms of bacterial metal sulfide oxidation-part A. Applied Microbiology and Biotechnology, 97(17), 752941. doi: 10.1007/s00253-013-4954-2

48. Xia W., Xie G., Peng Y. 2015. Recent advances in beneficiation for low rank coals, Powder Technology, 277, 206-221 